UDC 61

DOI: 10.21668/health.risk/2019.4.10.eng

\title{
MORBIDITY WITH ARTERIAL HYPERTENSION AMONG WORKERS INVOLVED IN NUCLEAR WEAPONRY UTILIZATION
}

\author{
K.V. Briks, M.V. Bannikova, T.V. Azizova, G.V. Zhuntova, E.S. Grigor'eva \\ The Southern Urals Biophysics Institute of the RF Federal Medical and Biological Agency, 19 Ozerskoe drive, \\ Ozersk, 456780, Russian Federation
}

Cardiovascular diseases remain a basic socially significant issue in most countries all over the world. Our research goal was to comparatively assess morbidity with arterial hypertension (ICD-9 codes 401-404 or ICD-10 codes I.10 -I.14) among workers involved in nuclear weaponry utilization. We examined an occupational cohort that included workers employed at chemical-metallurgical production of "Mayak" Production Association (PA). They were all employed in 1949-2014 and observed by medical personnel up to December 31, 2017; overall, the cohort included 10,908 people. We analyzed morbidity parameters taking into account both radiation factors (external gamma-irradiation and internal alpha-irradiation caused by incorporated plutonium) and basic non-radiation ones. Standardization was accomplished indirectly with an internal standard. Morbidity was calculated with medical statistics tools per 1,000 workers. We also assessed excess relative risk per one dose (ERR/Gy). As a result, we revealed that on December 31, 20172,270 arterial hypertension cases were registered in the examined cohort that included workers employed at "Mayak" PA who were involved in utilizing nuclear weaponry. We showed that standardized morbidity with arterial hypertension among workers employed at "Mayak" PA and involved in utilizing nuclear weaponry statistically significantly depended on nonradiation factors (sex, age, smoking status, attitude towards alcohol intake, body mass index, and pancreatic diabetes) and didn't depend on total dose of external gamma-irradiation and internal alpha-irradiation absorbed in the liver.

Key words: arterial hypertension, morbidity, external gamma-irradiation, internal alpha-irradiation, occupational irradiation, cohort study, "Mayak" $P$ A, nuclear weaponry utilization.

Cardiovascular diseases (CVD) remain a most socially significant problem in many countries all over the world. In particular, in Europe 4 million people annually die due to CVD; 1 million out of them are deaths in Russia [1]. In 2011 in Russia CVD-related mortality accounted for $55.9 \%$ out of overall mortality while in Europe the figure was $47 \%$ [2].

Circulatory system diseases (CSD) cause more than $1 / 3$ deaths among employable population, and mortality among men is higher than among women. It is 4.7 times higher for CSD as a whole; 7.2 times, for ischemic heart disease (IHD); 9.1, for cardiac infarction; and 3.4 times, for cerebrovascular diseases [3]. Despite a decrease in CVDcaused mortality that has occurred in developed countries and over the last few years in Russia also, the situation in the country remains serious as it is highlighted in multiple domestic and foreign research works $[1,4,5]$.

Arterial hypertension ( $\mathrm{AH})$ is a leading risk factor causing cardiovascular diseases (cardiac infarction, stroke, IHD, and chronic heart failure), cerebrovascular diseases (ischemic or hemorrhagic stroke, transient ischemic attack), and renal diseases (chronic renal disease).

$\mathrm{AH}$ prevalence in the world is different in different countries and varies from $27 \%$ in

(C) Briks K.V., Bannikova M.V., Azizova T.V., Zhuntova G.V., Grigor'eva E.S., 2019

Ksen'ya V. Briks - Junior Researcher (e-mail: clinic@subi.su; tel.: +7 (35130) 2-93-20; ORCID: https://orcid.org/00000001-8815-9742).

Mariya V. Bannikova - Junior Researcher (e-mail: clinic@subi.su; tel.: +7 (35130) 2-93-20; ORCID: https:// orcid.org/0000-0002-2755-6282).

Tamara V. Azizova - Candidate of Medical Sciences, Deputy Director responsible for Research, Head of the Clinical Department (e-mail: clinic@subi.su; tel.: +7 (35130) 2-91-90; ORCID: https://orcid.org/0000-0001-6954-2674).

Galina V. Zhuntova - Candidate of Medical Sciences, Leading Researcher (e-mail: clinic@subi.su; tel.: +7 (35130) 2-95-41; ORCID: https://orcid.org/0000-0003-4407-3749).

Evgeniya S. Grigor'eva - Researcher (e-mail: clinic@subi.su; tel.: +7 (35130) 2-93-73; ORCID: https://orcid.org/00000003-1806-9922). 
Iran to $67 \%$ in Poland; in developed countries it is approximately $41 \%[6,7]$. In the Russian Federation $\mathrm{AH}$ prevalence also amounts to approximately $42 \%$ [8].

Our research goal was to assess impacts exerted by radiation and non-radiation factors on morbidity with AH among workers employed at Mayak PA who took part in nuclear weaponry (NW) utilization.

Data and methods. Mayak Production Association or Mayak PA was the first atomic enterprise in the former USSR. Longterm chronic irradiation has always been the major occupational hazardous factor for workers employed at it. We selected a cohort that included workers employed at a chemical and metallurgic plant of the whole PA who started their work in 1949-2004 and took part in NW utilization. To do that, we used the Mayak PA medical and dosimetric register that contained data on each worker and was created and kept by the Radiation Epidemiology Laboratory of the Southern Urals Institute for Biophysics [9].

We observed workers included into the cohort for a period that started from their employment date and finished on either of the following days: a day when a circulatory system disease was diagnosed; a day of a worker's death; December 31, 2017 for those who were alive on that day; a date for which "the last medical data" were available for those workers who had moved from Ozersk to other places, or in case we couldn't find out whether a person was dead or alive on December 31, 2017.

There were 10,908 people in the examined cohort, $27.6 \%$ of them were females. We determined whether a person was dead or alive in $96.6 \%$ cases; $49.1 \%$ of them were dead, and $50.9 \%$, alive. A share of women accounted for $54.6 \%$ on the date when the observation finished. All the workers in the examined cohort had been exposed to occupational long-term irradiation (external gammairradiation and/or internal alpha-irradiation). As of state on December 31, 2017, data on diseases which workers in the examined cohort had suffered from during the overall observa- tion period were available for 5,877 (94.65\%) men and 1,764 (94.385) women.

Within our research, we analyzed morbidity with $\mathrm{AH}$ among workers employed at Mayak PA who had taken part in NW utilization as per 401-404 codes in ICD-9 or I 10-I 14 codes in ICD-10:

- Essential hypertension (401 in ICD-9 or I-10 in ICD-10);

- Hypertensive heart disease with congestive heart failure (402 in ICD-9 or I-11 in ICD-10);

- Hypertensive renal disease with congestive renal failure (403 in ICD-9 or I-12 in ICD-10);

- Hypertensive heart and renal disease with both congestive heart failure and renal failure (404 in ICD-9 or I-13 in ICD-10).

Initial data were statistically processed with Statistica 10 standard software. We calculated both non-standardized ("rough") morbidity parameters and standardized (as per sex and age) ones. We applied indirect standardization techniques to standardize the examined parameters. To do that, we applied an internal standard distributing the overall examined cohort of workers employed at Mayak PA as per their age. Morbidity parameters were calculated per 1,000 workers according to medical statistics techniques [10].

Parameters of morbidity with $\mathrm{AH}$ were analyzed taking into account both radiationrelated factors (external gamma-irradiation and internal alpha-irradiation caused by incorporated plutonium) and basic non-radiation ones (sex, age, smoking status, attitude towards alcohol intake, body mass index or BMI, as well as diagnosed pancreatic diabetes).

Data on attitudes workers had towards smoking were taken for the whole observation period and assessed with a qualitative parameter (smoked / didn't smoke).

Data on attitudes workers had towards alcohol intake were taken for the whole observation period and assessed with a quantitative parameter (chronic alcoholism; drank reasonably; didn't drink).

BMI was assessed over 5 years prior to a date when $\mathrm{AH}$ was first diagnosed. Body 
mass index was measured as a ratio of body mass in kilos $(\mathrm{KG})$ and height $\left(\mathrm{m}^{2}\right)$. BMI $=$ $=18.5-24.99 \mathrm{~kg} / \mathrm{m}^{2}$ was considered to be normal, BMI $=25.00-29.99 \mathrm{~kg} / \mathrm{m}^{2}$ meant a person had overweight, and BMI $\geq 30 \mathrm{~kg} / \mathrm{m}^{2}$ meant a person suffered from obesity.

The tables below contain non-standardized ("rough" or "intensive") and standardized (as per age) mortality and morbidity parameters \pm standard error (SE). We applied Student's t-test to assess whether discrepancies between mean values were statistically significant. Significance level was taken at $\mathrm{p}<0.05$ [11].

Results and discussion. As of state on December 31, 2017, 2,270 AH cases were registered among workers from the examined cohort who had been employed at Mayak PA and taken part in NW utilization. Table 1 shows AH cases distribution depending on a person's sex and age at the moment $\mathrm{AH}$ was diagnosed. The obtained data indicate that the greatest number of $\mathrm{AH}$ cases was registered among men aged 31-60 (70.56\%); and among women aged 41-70 (79.55\%).

Table 2 contains standardized parameters of morbidity with $\mathrm{AH}$ among the examined workers employed at Mayak PA who had taken part in NW utilization; parameters are standardized depending on a sex and age. Morbidity with AH statistically significantly increased both among men and women in the

Table 1

Workers suffering from $\mathrm{AH}$ distributed as per age and sex on a date the disease was first diagnosed

\begin{tabular}{|c|c|c|c|c|c|c|}
\hline \multirow{2}{*}{$\begin{array}{c}\text { Age on a day AH } \\
\text { was first diagnosed }\end{array}$} & \multicolumn{2}{|c|}{ Men } & \multicolumn{2}{c|}{ Women } & \multicolumn{2}{c|}{ Both sexes } \\
\cline { 2 - 7 } & Number & $\%$ & Number & $\%$ & Number & $\%$ \\
\hline$<20$ & 5 & 0.31 & 0 & 0 & 5 & 0.23 \\
\hline $21-30$ & 151 & 9.44 & 13 & 1.94 & 164 & 7.22 \\
\hline $31-40$ & 303 & 18.93 & 52 & 7.76 & 355 & 15.64 \\
\hline $41-50$ & 416 & 26 & 160 & 23.88 & 576 & 25.37 \\
\hline $51-60$ & 410 & 25.63 & 195 & 29.1 & 605 & 26.65 \\
\hline $61-70$ & 232 & 14.5 & 178 & 26.57 & 410 & 18.06 \\
\hline$>70$ & 83 & 5.19 & 72 & 10.75 & 155 & 6.83 \\
\hline Total & 1,600 & 100 & 670 & 100 & 2,270 & 100 \\
\hline
\end{tabular}

Table 2

Morbidity with AH among workers employed at Mayak PA who had taken part in NW utilization depending on sex and age at which the disease was first diagnosed

\begin{tabular}{|c|c|c|c|c|c|}
\hline \multirow{2}{*}{$\begin{array}{c}\text { Morbidity } \\
\text { parameters }\end{array}$} & \multirow{2}{*}{ Age } & \multicolumn{2}{|c|}{ Men } & \multicolumn{2}{c|}{ Women } \\
\cline { 3 - 6 } & $<20$ & Number of cases & Morbidity & Number of cases & Morbidity \\
\hline \multirow{5}{*}{ Intensive } & $20-29$ & 151 & $4.69 \pm 0.62 \mathrm{a}$ & 0 & $0 \pm 0$ \\
\cline { 2 - 6 } & $30-39$ & 303 & $9.48 \pm 0.54^{\mathrm{ab}}$ & 13 & $2.13 \pm 0.59^{\mathrm{b}}$ \\
\cline { 2 - 6 } & $40-49$ & 416 & $16.39 \pm 0.8^{\mathrm{b}}$ & 160 & $14.54 \pm 0.71^{\mathrm{b}}$ \\
\cline { 2 - 6 } & $50-59$ & 410 & $28.43 \pm 1.4^{\mathrm{b}}$ & 195 & $26.31 \pm 1.88^{\mathrm{b}}$ \\
\cline { 2 - 6 } & $60-69$ & 232 & $40.68 \pm 2.67^{\mathrm{ab}}$ & 178 & $53.53 \pm 4.01^{\mathrm{b}}$ \\
\cline { 2 - 4 } & $>70$ & 83 & $58.24 \pm 6.39^{\mathrm{b}}$ & 72 & $67.98 \pm 8.01$ \\
\cline { 2 - 4 } & Total & \multirow{2}{*}{1,600} & $15.11 \pm 0.36$ & \multirow{2}{*}{670} & $13.93 \pm 0.59$ \\
\hline \multirow{2}{*}{ Standardized } & $\begin{array}{c}\text { Internal } \\
\text { standard }\end{array}$ & & $13.96 \pm 0.35^{\mathrm{a}}$ & & $17.02 \pm 0.66$ \\
\hline
\end{tabular}

Note:

a means discrepancies are statistically significant when compared as per sex;

$\mathrm{b}$ means discrepancies are statistically significant against the previous age group. 
examined cohort as they grew older. Morbidity with $\mathrm{AH}$ was statistically significantly higher among men aged 20-39 than among women in the same age group. However, among people aged 60 and older the situation changed completely and morbidity with $\mathrm{AH}$ became statistically significantly higher among women than it was among men in this age group.

As life expectancy has been persistently growing, a share of elderly people in population structure has also been increasing. An increase in $\mathrm{AH}$ numbers among older people is considered to be well-proven and confirmed by results obtained via multiple research works, both in Russia and abroad; it was first highlighted in Framingham Heart Study. Arterial hypertension (AH) prevalence among people who are older than 60 is more than 2 times higher than this parameter for the overall population [12]; $2 / 3$ people older than 65 have $\mathrm{AH}$ [13].

Gender-related peculiarities in arterial hypertension $(\mathrm{AH})$ are determined not only with biological but also with social and cultural factors, namely different lifestyles, nutrition, and behavior patterns; different ways to fight stress; social and economic inequality; sleep disorders; mood disorders; different attitudes towards treatment and prevention of diseases etc. [14]. Besides, pregnancy or use of oral contraception and hormonal substitute therapy during menopause can influence mechanisms that regulate blood pressure (BP) in female bodies. All this contributes into cardiovascular pathology occurrence $[15,16]$.

There are also sex- and age-related differences in $\mathrm{AH}$ prevalence. According to some authors, women aged younger than 40 tend to suffer from $\mathrm{AH}$ not as frequently as men [15-19]. Besides, young women usually have lower systolic BP than men. Diastolic $\mathrm{BP}$, as a rule, is lower in women than in men regardless of an age. But the situation changes to an opposite one when it comes to 50 years of age. Morbidity among women starts to grow more intensively than among men and the parameter becomes comparable in both groups as they reach 60 years of age. After this age, $\mathrm{AH}$ prevalence is higher among women than among men. Therefore, favorable sex-related differences level off as menopause occurs [13, 15]. Higher blood pressure and arterial hypertension prevalence among women grows considerably after menopause starts [20, 21]. Sex hormones deficiency leads to disorders in vascular endothelium functioning, balance between various vasoactive substances, and functioning of cells in smooth muscles of vessels; it results in higher peripheral vessels resistance and, consequently, higher blood pressure [22].

In this research we focused on a dynamics of morbidity with $\mathrm{AH}$ among workers employed at Mayak PA over the whole observation period, starting from January 01, 1948 and till December 31, 2017 (Figure 1). "Rough" morbidity with AH increased by the end of the observation period due to an increase in workers' age in the examined cohort (that is, workers became "old enough" to have an age-associated pathology).

An increase in standardized morbidity with AH in 1986-2000 was probably due to a complicated social and economic situation in the country that was caused by perestroika in 1985-1991 and all the events that followed the collapse of the USSR in 1990-ties [23].

We analyzed dependence between morbidity with $\mathrm{AH}$ and smoking status; the results are given in Table 3 . We detected that there were no statistically significant discrepancies in standardized morbidity with $\mathrm{AH}$ among smoking and non-smoking men in the examined cohort. However, we detected statistically

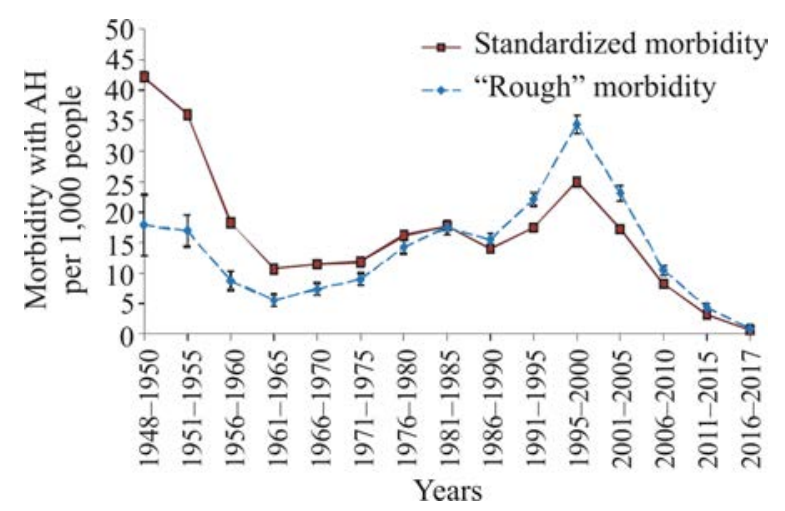

Figure 1. Dynamics of morbidity with AH over the whole observation period (01.01.1949-31.12.2017) 
Table 3

Morbidity with AH among workers employed at Mayak PA who had participated in NW utilization depending on a worker's sex and smoking status at the moment the disease was first diagnosed (per 1,000 workers)

\begin{tabular}{|c|c|c|c|c|}
\hline \multirow{3}{*}{ Sex } & \multicolumn{3}{|c|}{ Smoking status } \\
\cline { 2 - 5 } & \multicolumn{2}{|c|}{ Non-smokers } & \multicolumn{2}{c|}{ Smokers } \\
\cline { 2 - 5 } & Number of cases & Morbidity & Number of cases & Morbidity \\
\hline Men & 350 & $15.72 \pm 0.81(14.45 \pm 0.77)$ & 1246 & $15.28 \pm 0.42(14.31 \pm 0.41)$ \\
\hline Women & 626 & $14.58 \pm 0.65(18.07 \pm 0.72)$ & 41 & $9.28 \pm 1.54^{\mathrm{a}}\left(10.48 \pm 1.64^{\mathrm{a}}\right)$ \\
\hline
\end{tabular}

Note:

a means statistically significant discrepancies against non-smokers.

Rough morbidity is given in brackets.

significantly lower morbidity with $\mathrm{AH}$ among smoking women in the examined cohort against their non-smoking counterparts.

Morbidity with AH among men and women in the examined cohort who suffered from chronic alcoholism was statistically significantly lower than among those who drank reasonably or rarely (Table 4 ).

The data we obtained on impacts exerted by smoking status and alcohol intake on morbidity with $\mathrm{AH}$ are not consistent with results obtained by many domestic and foreign researchers [24-34]. These facts require further profound investigations and we plan to accomplish them at the next stage in our analysis of AH risk among workers employed at Mayak PA who had participated in NW utilization.

Our analysis revealed that morbidity with $\mathrm{AH}$ was statistically significantly higher among men in the examined cohort who suffered from pancreatic diabetes (PD) than among those who didn't have this disease. The same trend among women was detected only when rough morbidity with $\mathrm{AH}$ was analyzed (Table 5).

Our results are well in line with existing literature data. Arterial hypertension is the most widely spread cardiovascular disease and at the same time it is a significant risk factor that causes cardiovascular complications; when it is combined with PD, the risk grows considerably $[35,36]$. Besides, $\mathrm{AH}$ is considered to be a most widely spread complication of PD [37]. AH prevalence among patients with PD is three times higher than among those who don't suffer from it [38]. A $10-\mathrm{mmHg}$ increase in systolic blood pressure in patients suffering from PD leads to a $20 \%$ rise in a risk that cardiovascular complications occur. When AH occurs in a patient with PD, it leads to an elevated risk of not only macrovascular (ischemic heart diseases or IHD, heart failure, and stroke) but also microvascular complications (diabetic nephropathy, retinopathy). Damage to coronary, cerebral, and peripheral vessels results in macrovascular complications in case a person suffers from PD II; it to a great extent determines a clinical course of the disease. AH considerably increases risks of morbidity and mortality among patients with PD which are high as it is. Overall mortality among patients suffering from both $\mathrm{AH}$ and PD II is 4-7 times higher than among patients who have normal blood pressure and don't suffer from PD [39, 40].

Table 6 contains data on morbidity with AH among workers employed at Mayak PA who had participated in NW utilization depending on their BMI. Morbidity with AH was statistically significantly higher both among men and women who had $\mathrm{BMI} \geq 25$ than among those who had normal body mass.

Each fourth person in the world suffers either from overweight or obesity. There has been an increase in number of people suffering from obesity all over the world, both among adults and children. Prevalence of obesity and diseases associated with it has been steadily growing in the Russian Federation. As per data 
Table 4

Morbidity with AH among workers employed at Mayak PA who had participated in NW utilization depending on a worker's sex and attitudes towards alcohol intake at the moment the disease was first diagnosed (per 1,000 workers)

\begin{tabular}{|c|c|c|c|c|c|c|}
\hline \multirow{2}{*}{ Sex } & \multicolumn{7}{|c|}{ Attitudes towards alcohol intake } \\
\cline { 2 - 7 } & \multicolumn{2}{|c|}{ Never / rarely drinks } & \multicolumn{2}{c|}{ Reasonably } & \multicolumn{2}{c|}{ Chronic alcoholism } \\
\cline { 2 - 7 } & $\begin{array}{c}\text { Number } \\
\text { of cases }\end{array}$ & Morbidity & $\begin{array}{c}\text { Number } \\
\text { of cases }\end{array}$ & Morbidity & $\begin{array}{c}\text { Number } \\
\text { of cases }\end{array}$ & Morbidity \\
\hline Men & 147 & $\begin{array}{c}14.41 \pm 1.07 \\
(11.6 \pm 0.96)\end{array}$ & 1,046 & $\begin{array}{c}17.66 \pm 0.54^{*} \\
\left(17.12 \pm 0.53^{*}\right)\end{array}$ & 365 & $\begin{array}{c}12.35 \pm 0.65 \S \\
(12.33 \pm 0.65 \S)\end{array}$ \\
\hline Women & 407 & $\begin{array}{c}13.84 \pm 0.77 \\
(17.29 \pm 0.86)\end{array}$ & 241 & $\begin{array}{c}15.62 \pm 1.11 \\
(19.09 \pm 1.23)\end{array}$ & 10 & $\begin{array}{c}8.03 \pm 2.76^{*} \S \\
(9.47 \pm 2.99 * \S)\end{array}$ \\
\hline
\end{tabular}

Note:

a means statistically significant discrepancies against those who didn't drink;

b means statistically significant discrepancies against those who drank reasonably.

Rough morbidity is given in brackets.

Table 5

Morbidity with AH among workers employed at Mayak PA who had participated in NW utilization depending on a worker's sex and diagnosed pancreatic diabetes at the moment $\mathrm{AH}$ was first diagnosed (per 1,000 workers)

\begin{tabular}{|c|c|c|c|c|}
\hline \multirow{2}{*}{ Sex } & \multicolumn{4}{|c|}{ Pancreatic diabetes } \\
\cline { 2 - 5 } & \multicolumn{2}{|c|}{ PD diagnosed } & \multicolumn{2}{c|}{ PD not diagnosed } \\
\cline { 2 - 5 } & Number of cases & Morbidity & Number of cases & Morbidity \\
\hline \multirow{2}{*}{ Men } & 1,562 & $\begin{array}{c}14.93 \pm 0.36 \\
(13.69 \pm 0.35)\end{array}$ & 38 & $\begin{array}{c}30.35 \pm 7.46^{\mathrm{a}} \\
\left(69.68 \pm 11.3^{\mathrm{a}}\right)\end{array}$ \\
\hline \multirow{2}{*}{ Women } & 646 & $\begin{array}{c}13.69 \pm 0.59 \\
(16.57 \pm 0.65)\end{array}$ & 24 & $\begin{array}{c}26.11 \pm 8.38 \\
\left(64.49 \pm 13.16^{\mathrm{a}}\right)\end{array}$ \\
\hline
\end{tabular}

Note:

a means statistically significant discrepancies against those who didn't suffer from PD.

Rough morbidity is given in brackets.

Table 6

Morbidity with AH among workers employed at Mayak PA who had participated in NW utilization depending on a worker's sex and BMI at the moment the disease was first diagnosed (per 1,000 workers)

\begin{tabular}{|c|c|c|c|c|c|c|}
\hline \multirow{3}{*}{ Sex } & \multicolumn{6}{|c|}{ Body mass index } \\
\cline { 2 - 7 } & \multicolumn{2}{|c|}{$18.50-24.99$} & \multicolumn{2}{c|}{$25.00-29.99$} & \multicolumn{2}{c|}{$\geq 30.00$} \\
\cline { 2 - 7 } & $\begin{array}{c}\text { Number } \\
\text { of cases }\end{array}$ & Morbidity & $\begin{array}{c}\text { Number } \\
\text { of cases }\end{array}$ & Morbidity & $\begin{array}{c}\text { Number } \\
\text { of cases }\end{array}$ & Morbidity \\
\hline Men & 353 & $\begin{array}{c}15.49 \pm 0.77 \\
(13.6 \pm 0.72)\end{array}$ & 653 & $\begin{array}{c}19.9 \pm 0.72^{\mathrm{a}} \\
\left(17.03 \pm 0.67^{\mathrm{a}}\right)\end{array}$ & 275 & $\begin{array}{c}18.18 \pm 1^{\mathrm{a}} \\
(15.11 \pm 0.91)\end{array}$ \\
\hline Women & 52 & $\begin{array}{c}8.15 \pm 1.19 \\
(9.07 \pm 1.26)\end{array}$ & 208 & $\begin{array}{c}15.81 \pm 1.16^{\mathrm{a}} \\
\left(17.65 \pm 1.22^{\mathrm{a}}\right)\end{array}$ & 218 & $\begin{array}{c}17.75 \pm 1.29^{\mathrm{a}} \\
\left(20.45 \pm 1.39^{\mathrm{a}}\right)\end{array}$ \\
\hline
\end{tabular}

Note:

a means statistically significant discrepancies against workers with BMI equal to 18.50-24.99.

Rough morbidity is given in brackets. 
Morbidity with AH among workers employed at Mayak PA who had participated in NW utilization depending on a worker's sex and total dose of external gamma-irradiation absorbed in the liver (per 1,000 workers)

\begin{tabular}{|c|c|c|c|c|c|c|}
\hline \multirow{3}{*}{ Sex } & \multicolumn{4}{|c|}{ Total dose of external gamma-irradiation absorbed in the liver, Gy } \\
\cline { 2 - 7 } & \multicolumn{2}{|c|}{$<0.2$} & \multicolumn{2}{c|}{$0.2-0.5$} & \multicolumn{2}{c|}{$\geq 0.5$} \\
\cline { 2 - 7 } & Number of cases & Morbidity & Number of cases & Morbidity & Number of cases & Morbidity \\
\hline Men & 1,108 & $17.69 \pm 0.53$ & 238 & $18.52 \pm 1.33$ & 176 & $19.12 \pm 1.6$ \\
\hline Women & 486 & $17.26 \pm 0.92$ & 76 & $17.87 \pm 2.25$ & 76 & $17.74 \pm 2.18$ \\
\hline
\end{tabular}

Таблица 8

Morbidity with AH among workers employed at Mayak PA who had participated in NW utilization depending on a worker's sex and total dose of internal alpha-irradiation absorbed in the liver (per 1,000 workers)

\begin{tabular}{|c|c|c|c|c|c|c|}
\hline \multirow{3}{*}{ Sex } & \multicolumn{6}{|c|}{ Total dose of internal alpha-irradiation absorbed in the liver, Gy } \\
\cline { 2 - 7 } & \multicolumn{2}{|c|}{$<0.025$} & \multicolumn{2}{c|}{$0.025-0.05$} & \multicolumn{2}{c|}{$\geq 0.05$} \\
\cline { 2 - 7 } & Number of cases & Morbidity & Number of cases & Morbidity & Number of cases & Morbidity \\
\hline Men & 731 & $18.96 \pm 0.69$ & 119 & $19.08 \pm 2.13$ & 253 & $17.12 \pm 1.38$ \\
\hline Women & 364 & $18.21 \pm 1.08$ & 42 & $15.71 \pm 3.19$ & 146 & $19.97 \pm 2.08$ \\
\hline
\end{tabular}

obtained via ESSE-RF epidemiologic research (2013), prevalence of obesity tends to grow with age, both as per BMI and waist circumference (WC) [28]. Thus, in Russia $26.6 \%$ men and $24.5 \%$ women aged 35-44 suffer from obesity; $31.7 \%$ and $40.9 \%$ among those aged 45-54; and $35.7 \%$ and $52.1 \%$ among those aged 55-64 accordingly.

Obesity is a significant risk factor that can cause $\mathrm{AH}$. It was proven that $\mathrm{AH}$ in $85 \%$ developed in people with their BMI $>25 \mathrm{~kg} / \mathrm{m}^{2}$ and it was 5 times more frequent among such people than among those with normal body mass [41]. Literature data confirm that AH develops together with abdominal obesity in $48.7 \%$ cases [42].

There is a tight pathogenetic relation between obesity and $\mathrm{AH}$ [43]. AH combined with obesity is drawing attention of public healthcare experts due to it causing early disability, elevated risks of cardiovascular complications and untimely deaths among people who suffer from it as compared with population in general. Obesity is both an independent factor that causes cardiovascular complications and a probable trigger mechanism that stimulates $\mathrm{AH}$ occurrence [44].
As workers in the examined cohort had been exposed to occupational long-term external gamma-irradiation or internal alphairradiation caused by incorporated plutonium, we analyzed morbidity with $\mathrm{AH}$ depending on radiation factors (Tables 7 and 8). We didn't reveal any statistically significant influence exerted by either external gammairradiation or internal alpha-irradiation on morbidity with $\mathrm{AH}$ among workers who had participated in NW utilization.

Experts are still arguing whether irradiation exerts any influence on blood pressure in spite of all their efforts to clarify it [45-47]. A possible increase in morbidity with cardiovascular diseases caused by irradiation in small doses first attracted scientists' attention when they were analyzing several categories of non-carcinogenic diseases in people who had survived atomic bombing in Japan and had had their whole bodies irradiated within a range of doses less than 5-6 Gy [48]. Excess mortality caused by $\mathrm{AH}$ with damage to the heart associated with irradiation was detected in a cohort in a life span study (LSS cohort); an excess relative risk per a unit of a dose (ERR / Gy) amounted to 0.21 (90\% CI: 0.00; 
$0.45 ; p=0.003)$ [45]. Later, when an observation period was extended up to 2008 , a statistically significant dose - effect dependence was detected in the same cohort for AH-caused mortality as ERR / Gy amounted to 0.36 (95\% CI: $0.10 ; 0.68 ; p=0.004)[49,50]$. In the last Adult Health Study (AHS) Yamada et al. [46] detected excess risk of morbidity with hypertension that was related to irradiation. That risk was in general statistically insignificant; however, quadratic dose dependence for morbidity with hypertension turned out to be statistically significant. There was also an examination conducted on a cohort that included 61,017 liquidators of Chernobyl Disaster; the results indicated there was a statistically significant elevated risk of essential hypertension (ERR / Gy =0.36 (95 \% CI: 0.05; 0.71; $p=0.04)$ ) [47]. When an observation period for the same cohort was extended up to 2012, experts revealed a statistically significant trend in morbidity with $\mathrm{AH}$, namely its dependence on an irradiation dose as ERR / Gy amounted to 0.26 (95\% CI: $0.12 ; 0.41 ; p<0.001)$ [49].
Sasaki et al. were the first to describe statistically significant relationships between systolic and diastolic blood pressure and an irradiation dose [50].

Therefore, we plan to assess risks of morbidity with $\mathrm{AH}$ under chronic irradiation exposure at the next stage in our research and to determine a dose - effect relationship taking into account non-radiation factors.

Conclusion. We calculated standardized morbidity with $\mathrm{AH}$ for workers employed at Mayak PA who had participated in NW utilization. The results revealed that it was statistically significantly depended on non-radiation factors (sex, age, smoking status, attitudes towards alcohol intake, body mass index, and pancreatic diabetes) and didn't depend on a total dose of external gamma-irradiation and internal alpha-irradiation absorbed in the liver.

Funding. The research was not granted any sponsor support.

Conflict of interests. The authors declare there is no any conflict of interests.

\section{References}

1. Wilkins E., Wilson L., Wickramasinghe K., Bhatnagar P., Leal J., Luengo-Fernandez R., Burns R., Rayner M., Townsend N. European Cardiovascular Disease Statistics 2017. Brussels: European Heart Network, 2017. Available at: http://www.ehnheart.org/images/CVD-statistics-report-August-2017.pdf(04.06.2019).

2. Belov V.B., Rogovina A.G. The basic medical demographic indicators of population health of Russia up to 2013. Problemy sotsial'noi gigieny, zdravookhraneniya i istorii meditsiny, 2014, vol. 22, no. 6, pp. 18-22 (in Russian).

3. Russian statistical yearbook. Moscow, Rosstat Publ., 2017, 686 p. Available at: http:// www.gks.ru/free_doc/doc_2017/year/year17.pdf(04.06.2019) (in Russian).

4. Shal'nova S.A., Deev A.D. Russian mortality trends in the early XXI century: official statistics data. Kardiovaskulyarnaya terapiya i profilaktika, 2011, vol. 10, no. 6, pp. 5-10 (in Russian).

5. Oganov R.G., Maslennikova G.Ya. Demographic trends in the Russian Federation: the impact of cardiovascular disease. Kardiovaskulyarnaya terapiya i profilaktika, 2012, vol. 11, no. 2, pp. 5-10 (in Russian).

6. Chow C.K., Teo K.K., Rangarajan S., Islam S., Gupta R., Avezum A., Bahonar A., Chifamba J. [et al.]. PURE (Prospective Urban Rural Epidemiology) Study investigators. Prevalence, awareness, treatment, and control of hypertension in rural and urban communities in high-, middle, and low-income countries. JAMA, 2013, vol. 310, no. 9, pp. 959-968 (in Russian). DOI: 10.1001/jama.2013.184182

7. Rahimi K., Emdin C.A., MacMahon S. The epidemiology of blood pressure and its worldwide management. Circulation research, 2015, vol. 116, no. 6, pp. 925-936. DOI: 10.1161/CIRCRESAHA. 116.304723

8. Chazova I.E., Oshchepkova E.V. Results of the Federal (National) Project for prevention and treatment essential hypertension patients in Russia from 2002-2012 years. Vestnik Rossiiskoi akademii meditsinskikh nauk, 2013, vol. 68, no. 2, pp. 4-11 (in Russian). 
9. Koshurnikova N.A., Shilnikova N.S., Okatenko P.V., Kreslov V.V., Bolotnikova M.G., Sokolnikov M.E., Khokhriakov V.F., Suslova K.G. [et al.]. Characteristics of the cohort of workers at the Mayak nuclear complex. Radiation Research, 1999, vol. 152, no. 4, pp. 352-363. DOI: 10.2307/3580220

10. Merkov A.M., Polyakov L.E. Sanitarnaya statistika (posobie dlya vrachei) [Sanitary statistics (manual for physicians)]. Moscow, Atomizdat Publ., 1975, 384 p. (in Russian).

11. Zar J.H. Biostatistical Analysis. New Jersey, Prentice Hall Publ., 1999, 718 p.

12. Yoon S.S., Fryar C.D., Carroll M.D. Hypertension prevalence and control among adults: United States, 2011-2014. US Department of Health and Human Services, Centers for Disease Control and Prevention, National Center for Health Statistics, 2015, no. 220, pp. 1-8.

13. Mozaffarian D., Benjamin E.J., Go A.S., Arnett D.K., Blaha M.J., Cushman M., Das S.R., De Ferranti S. [et al.]. Heart disease and stroke statistics-2016 update a report from the American Heart Association. Circulation, 2016, vol. 133, no. 4, pp. 38-48. DOI: 10.1161/CIR.0000000000000366

14. Di Pilla M., Bruno R.M., Taddei S., Virdis A. Gender differences in the relationships between psychosocial factors and hypertension. Maturitas, 2016, no. 93, pp. 58-64. DOI: 10.1016/j.maturitas.2016.06.003

15. Smetnik V.P., Smetnik A.A. Female sex hormones and cardiovascular system. Meditsinskii sovet, 2011, no. 3-4, pp. 40-45 (in Russian).

16. Yureneva S.V., Mychka V.B., Ilyina L.M., Tolstov S.N. Cardiovascular risk factors in women and the role of sex hormones. Kardiovaskulyarnaya terapiya i profilaktika, 2011, vol. 10, no. 4, pp. 128-135 (in Russian).

17. Belenkov Yu.N., Fomin I.V., Badin Yu.V. Gendernye razlichiya v rasprostranennosti i effektivnosti lecheniya arterial'noi gipertenzii v Evropeiskoi chasti Rossiiskoi Federatsii: rezul'taty issledovaniya EPOKhA-2007 [Gender-related differences in prevalence and efficiency of arterial hypertension treatment in the European part of the Russian Federation: results of EPOKHA-2007 research]. Problemy zhenskogo zdorovya, 2011, vol. 6, no. 4, pp. 5-11 (in Russian).

18. Oganov R.G., Maslennikova G.Ya. Gender specifics of cardiovascular pathology. Kardiovaskulyarnaya terapiya i profilaktika, 2012, vol. 11, no. 4, pp. 101-104 (in Russian).

19. Oganov R.G., Timofeeva T.N., Koltunov I.E., Konstantinov V.V., BalanovaYu.A., Kapustina A.V., Lelchuk I.N., Shalnova S.A., Deev A.D. Arterial hypertension epidemiology in Russia; the results of 2003-2010 federal monitoring. Kardiovaskulyarnaya terapiya i profilaktika, 2011, vol. 10, no. 1, pp. 9-13 (in Russian).

20. Staessen J.A., Ginocchio G., Thijs L., Fagard R. Conventional and ambulatory blood pressure and menopause in a prospective population study. Journal of human hypertension, 1997, vol. 11, no. 8, pp. 507-514. DOI: 10.1038/sj.jhh.1000476

21. Wassertheil-Smoller S., Anderson G., Psaty B.M., Black H.R., Manson J., Wong N., Francis J., Grimm R. [et al.]. Hypertension and its treatment in postmenopausal women: baseline data from Women's Health Initiative. Hypertension, 2000, vol. 36, no. 5, pp. 780-789. DOI: 10.1161/01.hyp.36.5.780

22. Belyakov N.A., Seidova G.B., Dorofeev V.I., Zheltisheva G.A. Mechanisms of postmenopausal endothelial dysfunction. Problemy zhenskogo zdorovya, vol. 2, no. 4, pp. 54-60 (in Russian).

23. Balanova Yu.A., Shal 'nova S.A., Deev A.D., Konstantinov V.V., Kapustina A.V. Arterial hypertension among men and women in Moscow. Arterial'naya gipertenziya, 2013, vol. 19, no. 2, pp. 102-108 (in Russian).

24. Efremova Yu.E., Oshchepkova E.V., Zhernakova Yu.V., Chazova I.E., Yarovaya E.B., Shal'nova S.A., Rotar' O.P., Konradi A.O. [et al.]. Cardiovascular risk factors in people with high normal blood pressure in Russian population (based on data obtained in ESSE-RF epidemiological study). Sistemnye gipertenzii, 2017, vol. 14, no. 1, pp. 6-11 (in Russian).

25. Barbarash O.L., Karetnikova V.N., Kochergina A.M., Indukaeva E.V., Artamonova G.V. Cardiovascular risk factors and its association with target blood pressure level in reachment in patients with arterial hypertension in Kemerovo. Meditsina v Kuzbasse, 2016, vol. 15, no. 1, pp. 47-53 (in Russian). 
26. Drapkina O.M. Smoking and related problems in the practice of a cardiologist. Arterial'naya gipertenziya, 2010, vol. 16, no. 2, pp. 164-169 (in Russian).

27. Chazova I.E., Zhernakova Yu.V., Oshchepkova E.V., Shal'nova S.A., Yarovaya E.B., Konradi A.O., Boitsov S.A. Prevalence of Cardiovascular Risk Factors in Russian Population of Patients With Arterial Hypertension. Kardiologiya, 2014, vol. 54, no. 10, pp. 4-12 (in Russian).

28. Balanova Iu.A., Kontsevaia A.V., Shal'nova S.A., Deev A.D., Artamonova G.V., Gatagonova T.M., Dupliakov D.V., Efanov A.Yu. [et al.]. Prevalence of behavioral risk factors for cardiovascular disease in the Russian population: Results of the ESSE-RF epidemiological study. Profilakticheskaya meditsina, 2014, vol. 17, no. 5, pp. 42-52 (in Russian).

29. Efanov A. Yu., Storozhok M.A., Sholomov I.F., Medvedeva I.V., Shalaev S.V. Prevalence of cardiovascular risk factors in nonorganized population of 25-64 year olds in Tyumen region. Results of ESSE-RF study in Tyumen region. Kardiovaskulyarnaya terapiya i profilaktika, 2016, vol. 15, no. 4, pp. 60-65 (in Russian). DOI: 10.15829/1728-8800-2016-4-60-65

30. Maksimov S.A., Indukaeva E.V., Skripchenko A.E., Cherkass N.V., Pavlova S.V., Artamonova G.V. Prevalence of major factors of cardiovascular risk in Kemerovo region: results of multicenter epidemiological research «ESSE-RF». Meditsina v Kusbasse, 2014, vol. 13, no. 3, pp. 36-42 (in Russian).

31. Muromtseva G.A., Kontsevaya A.V., Konstantinov V.V., Artamonova G.V., Gatagonova T.M., Duplyakov D.V., EfanovA.Yu., ZhernakovaYu.V. [et al.]. The prevalence of non-infectious diseases risk factors in Russian population in 2012-2013 years. The results of «ESSE-RF». Kardiovaskulyarnaya terapiya i profilaktika, 2014, vol. 13, no. 6, pp. 4-11 (in Russian). DOI: 10.15829/1728-8800-2014-6-4-11

32. Maksimov S.A., Danilchenko Ya.V., Tabakaev M.V., Mulerova T.A., Indukaeva E.V., Artamonova G.V. The relation of alcohol consumption with cardiovascular diseases and risk factors («ESSE-RF» trial in Kemerovskaya oblast'). Rossiiskii kardiologicheskii zhurnal, 2017, vol. 22, no. 9, pp. 65-70 (in Russian). DOI: 10.15829/1560-4071-2017-9-65-70

33. Poteshkina N.G., Krylova N.S., Adzhigaitkanova S.K., Troshina A.A. Alcohol in prevention of cardiovascular pathology: known and unknown. Rossiiskii kardiologicheskii zhurnal, 2015, vol. 20, no. 6, pp. 100-105 (in Russian). DOI: 10.15829/1560-4071-2015-06-100-105

34. Maksimov S.A., Tsygankova D.P., Artamonova G.V. Frequency of cardiovascular risk factors in relation to the volumes of alcohol consumption (the ESSE-RF study in the Kemerovo Region). Profilakticheskaya meditsina, 2017, vol. 20, no. 6, pp. 91-96 (in Russian). DOI: 10.17116/profmed201720691-96

35. Mogensen C.E. New treatment guidelines for a patient with diabetes and hypertension. J. Hypertens. Suppl., 2003, vol. 21, no. 1, pp. 25-30.

36. Haffner S.M., Lehto S., Ronnemaa T., Pyörälä K., Laakso M. Mortality from coronary heart disease in subjects with type 2 diabetes and in nondiabetic subjects with and without prior myocardial infarction. N. Engl. J. Med., 1998, vol. 339, no. 4, pp. 229-234. DOI: 10.1056/NEJM199807233390404

37. Vaidya V., Gangan N., Sheehan J. Impact of cardiovascular complications among patients with type 2 diabetes mellitus: a systematic review. Expert Rev. Pharmacoecon Outcomes Res., 2015, vol. 15, no. 3, pp. 487-497. DOI: 10.1586/14737167.2015.1024661

38. Dedov I.I., Shestakova M.V. Sakharnyi diabet i arterial'naya gipertenziya [Pancreatic diabetes and arterial hypertension]. Moscow, MIA Publ., 2006, 344 p. (in Russian).

39. Sarwar N., Gao P., Seshasai S.R. Diabetes mellitus, fasting blood glucose concentration, and risk of vascular disease: a collaborative meta-analysis of 102 prospective studies. Lancet, 2010, vol. 9733, no. 375, pp. 2215-2222. DOI: 10.1016/S0140-6736(10)60484-9

40. Sur G., Sur M., Kudor-Szabadi L., Sur L., Sporis D., Sur D. Arterial hypertension - prevalence of risk factors and morbide associations that increase cardiovascular risk. Maedica (Buchar), 2010, vol. 5, no. 1, pp. 34-40.

41. Haslam D.W., James W.P. Obesity. Lancet, 2005, vol. 366, no. 9492, pp. 1197-1209. DOI: 10.1016/S0140-6736(05)67483-1 
42. Nsiah K., Shang V.O., Boateng K.A., Mensah F.O. Prevalence of metabolic syndrome in type 2 diabetes mellitus patients. Int J. Appl. Basic. Med. Res., 2015, vol. 5, no. 2, pp. 133-138. DOI: $10.4103 / 2229-516 X .157170$

43. Drapkina O.M., Chaperkina S.O. Interrelation of metabolic syndrome, aseptic inflammation and endothelial dysfunction. Rossiiskie meditsinskie vesti, 2007, vol. 12, no. 3, pp. 67-76 (in Russian).

44. Lee Y., Huxley R.R., Wildman R.P., Woodward M. Indices of abdominal obesity are better discriminators of cardiovascular risk factors than BMi: a meta-analysis. Journal of Clinical epidemiology, 2008, vol. 61, no. 7, pp. 646-653. DOI: 10.1016/j.jclinepi.2007.08.012

45. Shimizu Y., Kodama K., Nishi N., Kasagi F., Suyama A., Soda M., Grant E.J., Sugiyama H. [et al.]. Radiation exposure and circulatory disease risk: Hiroshima and Nagasaki atomic bomb survivor data, 1950-2003. BMJ, 2010, vol. 340, pp. b5349. DOI: 10.1136/bmj.b5349

46. Yamada M., Wong F.L., Fujiwara S., Akahoshi M., Suzuki G. Noncancer disease incidence in atomic bomb survivors, 1958-1998. Radiat. Res., 2004, vol. 161, no. 6, pp. 622-632. DOI: 10.1667/RR3183

47. Ivanov V.K., Maksyutov M.A., Chekin S.Y., Petrov A.V., Biryukov A.P., Kruglova Z.G., Matyash V.A., Tsyb A.F. [et al.]. The risk of radiation-induced cerebrovascular disease in Chernobyl emergency workers. Health Phys, 2006, vol. 90, no. 3, pp. 199-207. DOI: 10.1097/01.HP.0000175835.31663.ea

48. Takahashi I., Shimizu Y., Grant E.J., Cologne J., Ozasa K., Kodama K. Heart Disease Mortality in the Life Span Study, 1950-2008. Radiat Res., 2017, vol. 187, no. 3, pp. 319-332. DOI: 10.1667/RR14347.1

49. Ivanov V.K., Chekin S.Yu., Maksyutov M.A., Kashcheev V.V., Karpenko S.V., Tumanov K.A., Korelo A.M., Kochergina E.V. [et al.]. Radiation Risk of Incidence of Hypertensia among Russian Recovery Operation Workers of the Chernobyl Accident. Meditsinskaya radiologiya i radiatsionnaya bezopasnost', 2017, vol. 62, no. 1, pp. 32-37 (in Russian). DOI: 10.12737/25050

50. Sasaki H., Wong F.L., Yamada M., Kodama K. The effects of aging and radiation exposure on blood pressure levels of atomic bomb survivors. J. Clin. Epidemiol., 2002, vol. 55, no. 10, pp. 974-981. DOI: $10.1016 / \mathrm{S} 0895-4356(02) 004390$

Briks K.V., Bannikova M.V., Azizova T.V., Zhuntova G.V., Grigor'eva E.S. Morbidity with arterial hypertension among workers involved in nuclear weaponry utilization. Health Risk Analysis, 2019, no. 4, pp. 93-103. DOI: 10.21668/health.risk/2019.4.10.eng

Received: 10.06 .2019

Accepted: 01.12.2019

Published: 30.12.2019 